\title{
Therapeutic management of an injury of the upper incisor within complete root formation
}

\author{
Maria Mielnik-BŁaszczak, Anna Struska, Katarzyna Rudnicka-Siwek, \\ Magdalena Warsz, Piotr Stachurski, ElżBieta Pels, Rafae Wróbel*
}

Chair and Department of Paedodontics Medical University of Lublin, ul. Karmelicka 7 (SCK), 20-081 Lublin, Poland

\section{ARTICLE INFO \\ Received 14 November 2015 Accepted 27 November 2015}

\section{Keywords:}

injuries of teeth,

root fractures,

dental injury epidemiology,

complications of dental injury.

\begin{abstract}
A 9.5 year-old patient, following an accident, suffered a comminuted lateral fracture of the root of tooth 21 at the neck level. The treatment consisted of immobilizing and maintaining tooth vitality. The presented case provides a basis for the conclusion that premature radical, surgical and endodontic actions should not always be performed.
\end{abstract}

\section{INTRODUCTION}

Injuries of teeth in childhood are very common, particularly among boys, and account for about $14 \%$ of all cases $[1,2]$. Among all such injuries, fractures of the roots of the tooth occur least frequently, constituting $0.5-7 \%$ of the total $[3,4]$. The most common of such occurrences are injuries of the maxillary central incisors. Fractures of the roots are located, in most cases, between the middle and the apical third of the root. Least likely are an occurrence around the neck of the tooth. $\mathrm{N}$ such situations, the prognosis is better in the case of lateral than oblique or longitudinal fracture. The location of the fracture line is also important; closer to the apex is most favorable. The success of the therapy also depends on the stage of root development - root-fractured teeth with immature roots have a better chance of showing good healing than teeth with mature roots [9].

Rarity, difficult diagnosis, long-term therapeutic procedure, as well as the frequent complications that come about, prompt an insightful description of this type of case.

\section{A CASE REPORT}

In September 2014, a 9.5 year-old patient was referred to the Department of Developmental Age Dentistry, Medical University of Lublin, due to injury of tooth 21 . The injury had occurred in August during a scooter crash. In the interview, the mother said that on the day of the injury, she had come to the dental office where the dental surgeon provided first aid. According to the mother's report, tooth

\footnotetext{
^ Corresponding author

e-mail: passero1@wp.pl
}

21 was inclined at an angle of about 45 degrees labially. The patient was generally healthy, neither lost consciousness nor suffered other injuries. The dental surgeon only repositioned the tooth and referred the child to the children's dentist. On the next day, the patient returned to the dental office and had a radiograph taken. It showed a comminuted fracture of the root around the neck of the tooth and the incomplete development of the root apex. A composite rigid splinting was provided comprising of the two adjacent teeth. The patient was referred for further treatment to our Department, and reported to us within a month.

The intra-oral examination revealed the presence of a broken composite rigid splinting, but, nevertheless, it had restricted the mobility of the tooth 21 . A current radiograph was made, which confirmed a comminuted fracture of the root around the neck of the tooth and the lack of resorption (Fig. 1). After removal of the rigid splinting, a slight anterior-posterior mobility of the tooth, with about $3 \mathrm{~mm}$ amplitude, was noted. The tooth also showed a reduced response to thermal stimuli. The rigid fixation of teeth by way of a steel orthodontic arch was made by attaching it to the teeth (13 to 23) using a composite. A pulpy diet and increased oral hygiene was recommended.

Control follow-up examinations of the state of the pulp and periapical tissues were performed every month. They showed a lack of pathological periodontal response, and the condition of pulp vitality to thermal stimuli remained at the same level. There was, however, no change in the color of the crown of the tooth, and the patient did not complain of any pain. At each examination, attention was drawn to very poor oral hygiene. Subsequent radiographs showed no signs 
of resorption, but also a widening of the periodontal cracks, and no signs of healing of the fracture line (Fig. 2). It was only after 14 months (in a radiograph) that the first signs of healing within the fracture line were noticed in the form of mineralized tissue and narrowing of the canal (Fig. 3). The response to thermal stimuli was still reduced. After orthodontic consultation, it was decided to leave the ligatures in place due to a very unfavorable location of the fracture line in the area of the tooth neck, as well as the presence of undershot in the patient. Still, in view of a satisfactory course of treatment, but incomplete fusion of the bone fragments, the above-described treatment will be continued.

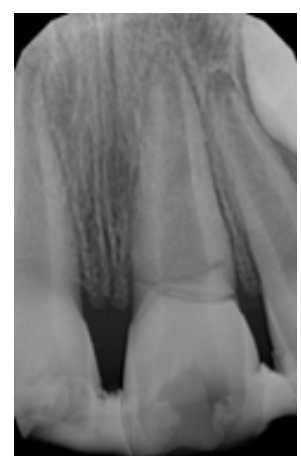

Figure 1. The state at 1 week after injury

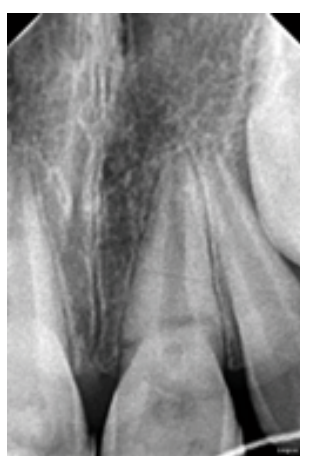

Figure 2. The state at 5 months after the injury - no signs of resorption

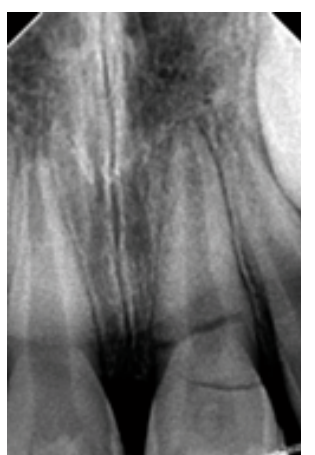

Figure 3. The state at 14 months after injury. The healing of the fractured root using mineralized tissue around the fracture line of the dental root 21

\section{DISCUSSION}

In patients at the developmental age, it is important to maintain full dentition. Premature loss of teeth can inhibit the proper development of the masticatory system, impair the aesthetics, as well as mouth functionality. In the case of dental root fractures, it is very important to maintain the vitality of the pulp as this ensures the healing of the fracture and the normal development of the dental root, as well as largely eliminates complications. This is facilitated by the presence of a wide apical opening as in the case described by us. Loss of pulp vitality usually occurs after 3 months and leads to the inflammatory resorption. According to Szczepańska and Pawłowska, the healing with mineralized tissue formation occurs only when the pulp retains its vitality [7]. This is confirmed in research by Cvek et al., wherein $78 \%$ of all cases, the living pulp guaranteed the formation of mineralized tissue [8]. The worst prognosis is where the location of root fracture is in the region of a dental neck, as the case described above. Most authors suggest removal of the fracture segment, i.e. the crown and possible orthodontic treatment involving the extrusion of the root for prosthetic treatment [8]. In the described case, the principle HANDS OFF was used, that is rigid fixation of the tooth was made and premature surgery and endodontic treatment was not effected $[3,5,6]$.

In the above described case, the patient's overall health was very good. However, the individual's oral health, despite many reminders, was very bad, and yet the healing process seems to proceed normally.

Regardless of the final result of treatment described by us, it is important to share the results of applied therapy due to the very difficult treatment of this type of dental root injury.

\section{CONCLUSIONS}

The above case shows that a bad prognosis of comminuted fracture of the tooth root at the level of the tooth neck involving a 9.5 year-old child provides the basis to conclude that premature radical surgical and endodontic actions should not be done.

\section{REFERENCES}

1. Andreasen J.O. i wsp.: Pourazowe uszkodzenia zębów. Urban\& Partner, Wrocław 2005, 10-17, 36-37, 60-63.

2. Cićkiewicz M., Jodkowska E., Wąsowicz M., Jurkowski P.: Skuteczność metod leczenia niepowikłanych złamań koron zębów stałych. Mag. Stomatol., 2010:20(9), s. 56-58.

3. Jurczak A., Kwapińska H., Kołodziej I., Starowicz M.: Leczenie wewnątrzzębodołowych poprzecznych złamań korzeni zębów u dzieci. Porad. Stomatol., 2008:8(2), s. 48-51.

4. Mrozek J., Jarosz J., Lipski M.: Leczenie złamania poprzecznego korzenia siekacza przyśrodkowego szczęki. Mag. Stomatol., 2009:19(11), s. 30-33.

5. Ozbek M., Serper A., Calt S.: Repair of untreated horizontal root fracture: a case report. Dent. Traumatol., 2003:19(5), s. 296-297.

6. Oztan M.D., Sonat B.: Repair of untreated horizontal root fractures: two case reports. Dent. Traumatol., 2001:17(5), s. 240-243.

7. Pawłowska E., Szczepańska J.: Złamania korzeni zębów stałych w wieku rozwojowym- procesy gojenia, powikłania-opis przypadków. Czas. Stomatol., 2005:58(2), s. 81-87.

8. Rahnama M., Szyszkowska A., Orzędała-Koszel U., Weiss A.: Odległe skutki przebytych urazów zębów u dzieci. E-Dentico, 2012(4), s. 88-97.

9. Rybarczyk-Townsend E., Hilt A., Szczepańska J.: Złamania poprzeczne korzeni z przemieszczeniem stałych zębów siecznych przyśrodkowych w szczęce. Mag. Stomatol., 2013:23(12), s. 36-40. 